\title{
Front Matter: Volume 10481
}

, "Front Matter: Volume 10481," Proc. SPIE 10481, Neural Imaging and Sensing 2018, 1048101 (2 May 2018); doi: 10.1117/12.2315741

SPIE. Event: SPIE BiOS, 2018, San Francisco, California, United States 
PROGRESS IN BIOMEDICAL OPTICS AND IMAGING

Vol. 19 No. 15

\title{
Neural Imaging and Sensing 2018
}

\author{
Qingming Luo \\ Jun Ding \\ Editors
}

29-30 January 2018

San Francisco, California, United States

Sponsored and Published by

SPIE

Volume 10481 
The papers in this volume were part of the technical conference cited on the cover and title page. Papers were selected and subject to review by the editors and conference program committee. Some conference presentations may not be available for publication. Additional papers and presentation recordings may be available online in the SPIE Digital Library at SPIEDigitalLibrary.org.

The papers reflect the work and thoughts of the authors and are published herein as submitted. The publisher is not responsible for the validity of the information or for any outcomes resulting from reliance thereon.

Please use the following format to cite material from these proceedings:

Author(s), "Title of Paper," in Neural Imaging and Sensing 2018, edited by Qingming Luo, Jun Ding, Proceedings of SPIE Vol. 10481 (SPIE, Bellingham, WA, 2018) Seven-digit Article CID Number.

ISSN: 1605-7422

ISSN: 1996-756X (electronic)

ISBN: 9781510614475

ISBN: 9781510614482 (electronic)

Published by

SPIE

P.O. Box 10, Bellingham, Washington 98227-0010 USA

Telephone +1 3606763290 (Pacific Time) · Fax +1 3606471445

SPIE.org

Copyright (C) 2018, Society of Photo-Optical Instrumentation Engineers.

Copying of material in this book for internal or personal use, or for the internal or personal use of specific clients, beyond the fair use provisions granted by the U.S. Copyright Law is authorized by SPIE subject to payment of copying fees. The Transactional Reporting Service base fee for this volume is $\$ 18.00$ per article (or portion thereof), which should be paid directly to the Copyright Clearance Center (CCC), 222 Rosewood Drive, Danvers, MA 01923. Payment may also be made electronically through CCC Online at copyright.com. Other copying for republication, resale, advertising or promotion, or any form of systematic or multiple reproduction of any material in this book is prohibited except with permission in writing from the publisher. The CCC fee code is 1605 $7422 / 18 / \$ 18.00$.

Printed in the United States of America.

Publication of record for individual papers is online in the SPIE Digital Library.

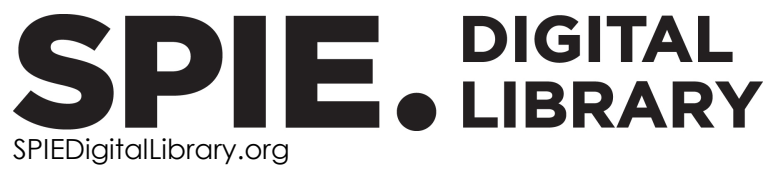

Paper Numbering: Proceedings of SPIE follow an e-First publication model. A unique citation identifier (CID) number is assigned to each article at the time of publication. Utilization of CIDs allows articles to be fully citable as soon as they are published online, and connects the same identifier to all online and print versions of the publication. SPIE uses a seven-digit CID article numbering system structured as follows:

- The first five digits correspond to the SPIE volume number.

- The last two digits indicate publication order within the volume using a Base 36 numbering system employing both numerals and letters. These two-number sets start with 00, 01, 02, 03, 04, 05, 06, 07, 08, 09, OA, OB ... 0Z, followed by 10-1Z, 20-2Z, etc. The CID Number appears on each page of the manuscript. 


\title{
Contents
}

\author{
$\checkmark$ Authors \\ vii Conference Committee
}

IN VIVO MOUSE BRAIN IMAGING I

10481 OA Deep brain two-photon NIR fluorescence imaging for study of Alzheimer's disease [10481-4]

BRAIN-WIDE IMAGING I

10481 ol Imaging whole mouse brains with a dual resolution serial swept-source optical coherence tomography scanner [10481-12]

NOVEL TECHNOLOGIES I

10481 OS Nanomedicine photoluminescence crystal-inspired brain sensing approach [10481-24]

NOVEL TECHNOLOGIES II

10481 OW UbasM: a simple, rapid, efficient balanced optical clearing method for brain imaging [10481-29]

HUMAN BRAIN IMAGING

10481 OY Low-frequency oscillation amplitude elevation of prefrontal cerebral hemodynamics with driving duration during prolonged driving test [10481-31]

OPTICAL SENSING AND IMAGING FOR BRAIN DISEASES

1048113 Long term imaging of living brain cancer cells [10481-36]

POSTER SESSION

10481 1C Change in cognitive process during dance video game play with different appendages for motor output [10481-45] 
10481 1G Voluntary exercise confers protection against age-related deficits in brain oxygenation in awake mice model of Alzheimer's disease [10481-50]

$10481 \mathrm{lH}$ Hemodynamic monitoring in different cortical layers with a single fiber optical system [10481-51]

1048111 Comparison of seven optical clearing methods for mouse brain [10481-52]

10481 iN Measurement of shear-induced diffusion of red blood cells using dynamic light scatteringoptical coherence tomography [10481-57]

10481 IT Automatic tissue image segmentation based on image processing and deep learning [10481-63]

10481 1X High-throughput isotropic mapping of whole mouse brain using multi-view light-sheet microscopy [10481-67] 


\title{
Authors
}

Numbers in the index correspond to the last two digits of the seven-digit citation identifier (CID) article numbering system used in Proceedings of SPIE. The first five digits reflect the volume number. Base 36 numbering is employed for the last two digits and indicates the order of articles within the volume. Numbers start with 00, 01, 02, 03, 04, 05, 06, 07, 08, 09, OA, OB...0Z, followed by 10-1Z, 20-2Z, etc.

\author{
Andrade, Arnaldo C. D. S., 13 \\ Boas, David A., $1 \mathrm{~N}$ \\ Carp, Stefan A., IN \\ Castonguay, Alexandre, 01 \\ Chen, Congping, OA \\ Chen, Lingling, OW \\ Deng, Zishan, OY \\ Erdener, Sefik Evren, IN \\ Fang, Yan, OS \\ Farias, Patricia M. A., 13 \\ Fei, Peng, $1 \mathrm{X}$ \\ Fu, Buyin, 1N \\ Galembeck, André, 13 \\ Gao, Yuan, OY \\ Ip, Nancy Y., OA \\ Kiss, Zelma H. T., 1H \\ Kong, Zhenglun, $1 \mathrm{~T}$ \\ Lee, Jonghwan, $1 \mathrm{~N}$ \\ Lefebvre, Joël, ol \\ Lesage, Frédéric, OI, IG \\ Li, Baoqiang, 1G, 1N \\ Li, Guiye, OW \\ Li, Ting, OY, IT \\ Li, Yingchao, OW \\ Li, Yusha, 1X \\ Liang, Zhuoyi, OA \\ Liv, Ang, OW \\ Liu, Lina, OW \\ Liu, Sa, $1 \mathrm{X}$ \\ LU, Xuecong, $1 G$ \\ Luo, Junyi, IT \\ Milani, Raquel, 13 \\ Moeini, Mohammad, $1 G$ \\ Murari, Kartikeya, $1 \mathrm{H}$ \\ Nie, Jun, $1 X$ \\ Noah, Jack Adam, 1C \\ Noor, M. Sohail, $1 \mathrm{H}$ \\ Ono, Yumie, 1C \\ Ping, Junyu, $1 X$ \\ QU, Jianan Y., OA \\ Ruan, Shuangchen, OW \\ Sakadžić, Sava, 1G, IN \\ Shimada, Sotaro, 1C \\ Stingl, Andreas, 13 \\ Suzuki, Kota, 1C \\ Tachibana, Atsumichi, $1 \mathrm{C}$ \\ Tang, Jianbo, $1 \mathrm{~N}$ \\ Wan, Peng, 11 \\ Wang, Fangzhen, OS
}

Wu, Rong, OS

$\mathrm{XU}$, Shengpu, $1 \mathrm{~T}$

Yu, Linhui, $1 \mathrm{H}$

Yu, Tingting, 11, $1 \mathrm{X}$

Zhao, Fang, $1 \mathrm{X}$

Zhou, Biao, OA

Zhu, Dan, 11, 1X

Zhu, Jingtan, 11 
Proc. of SPIE Vol. 10481 1048101-6

Downloaded From: https://www.spiedigitallibrary.org/conference-proceedings-of-spie on 26 Apr 2023 Terms of Use: https://www.spiedigitallibrary.org/terms-of-use 


\title{
Conference Committee
}

\author{
Symposium Chairs
}

James G. Fujimoto, Massachusetts Institute of Technology

(United States)

R. Rox Anderson, Wellman Center for Photomedicine, Massachusetts General Hospital (United States) and Harvard Medical School (United States)

Program Track Chairs

Rafael Yuste, Columbia University (United States)

David A. Boas, Boston University (United States)

Conference Chairs

Qingming Luo, Huazhong University of Science and Technology (China)

Jun Ding, Stanford School of Medicine (United States)

\section{Conference Program Committee}

Robert R. Alfano, The City College of New York (United States)

David A. Boas, Massachusetts General Hospital (United States)

Shih-Chi Chen, The Chinese University of Hong Kong (Hong Kong, China)

Yu Chen, University of Maryland, College Park (United States)

Javier Defelipe, Universidad Politécnica de Madrid (Spain)

Hongwei Dong, University of California, Los Angeles (United States)

Congwu Du, Stony Brook University (United States)

Beop-Min Kim, Korea University (Korea, Republic of)

Pengcheng Li, HUST-SUzhou Institute for Brainsmatics (China)

Byungkook Lim, University of California, San Diego (United States)

Francesco Saverio Pavone, European Laboratory for Non-linear

Spectroscopy (Italy)

Darcy S. Peterka, Columbia University (United States)

Kambiz Pourrezaei, Drexel University (United States)

Claus-Peter Richter, Northwestern University (United States)

Anna W. Roe, Zhejiang University (China)

Oxana V. Semyachkina-Glushkovskaya, Saratov State University (Russian Federation)

Shy Shoham, Technion-Israel Institute of Technology (Israel) 
Shaoqun Zeng, Huazhong University of Science and Technology (China)

\section{Session Chairs}

1 In Vivo Mouse Brain Imaging I

Qingming Luo, Huazhong University of Science and Technology (China)

2 In Vivo Mouse Brain Imaging II

Ling Fu, Huazhong University of Science and Technology (China)

3 Brain-Wide Imaging I

David A. Boas, Boston University (United States)

4 Brain-Wide Imaging II

Francesco Saverio Pavone, European Laboratory for Non-linear Spectroscopy (Italy)

5 Novel Technologies I

Beop-Min Kim, Korea University (Korea, Republic of)

6 Novel Technologies II

Jun Ding, Stanford University Medical Center (United States)

$7 \quad$ Human Brain Imaging

Yu Chen, University of Maryland, College Park (United States)

8 Optical Sensing and Imaging for Brain Diseases

Shy Shoham, Technion-Israel Institute of Technology (Israel) 